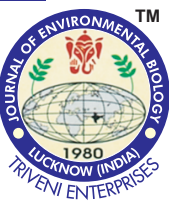

\title{
Evaluating the effect of monocrotophos and glyphosate on microbial population and certain important exoenzyme activities in soil
}

\begin{tabular}{llll}
\hline Paper received: 02.01.2018 Revised received: 25.04 .2018 & Re-revised received: 20.06 .2018 & Accepted: 11.07 .2018
\end{tabular}

\section{Authors Info \\ S. Samal', S. Sahoo and C.S.K Mishra* \\ ${ }^{1}$ Department of Zoology, College of Basic Science and Humanities, Orissa University of Agriculture and Technology Bhubaneswar-751 003, India \\ ${ }^{2}$ School of Life Sciences, Sambalpur University, Jyoti Vihar, Burla-768 019, India \\ *Corresponding Author Email : cskmishra@yahoo.com}

\section{Edited by \\ Dr. R. B. Raizada}

\section{Reviewed by}

Dr. Priyanka Chandra

Dr. Madhu Chaudhary

\section{Abstract}

Aim : The study aimed to evaluate the effects of various concentrations of organophosphate agrochemicals, namely monocrotophos and glyphosate on soil chemical parameters, microbial population and activities of certain vital exoenzymes e.g. invertase, amylase, cellulase, dehydrogenase and protease at 7 days interval over an incubation period of 84 days.

Methodology : Three concentrations of monocrotophos (1.0 $\mathrm{g} \mathrm{kg}^{-1}$ soil-low T1, $2.0 \mathrm{~g} \mathrm{~kg}^{-1}$ soil-medium T2, 3.0 $\mathrm{g} \mathrm{kg}^{-1}$ soil-high T3) and glyphosate ( $0.1 \mathrm{~g} \mathrm{~kg}^{-1}$ soil-low T1, $0.15 \mathrm{~g} \mathrm{~kg}^{-1}$ soil-medium T2, $0.2 \mathrm{~g} \mathrm{~kg}^{-1}$ soil-high T3) were applied to soil. Soil pH, electrical conductivity, organic carbon (OC), available nitrogen, phosphorous and potassium (NPK) were assessed. Bacterial and fungal population along with activities of exoenzymes were also studied. Data were analysed using two way ANOVAand Duncan's multiple range test (DMRT).

Results : Significant variations $(p<0.05)$ of chemical parameters, except $P$ and $K$, in treated soil between concentrations and time over the incubation period were observed. Microbial population and exoenzymes showed significant variations $(p<0.05)$ in response to agrochemical treatments. Invariably, lower microbial load and enzyme activities were noticed in treated soil relative to control.

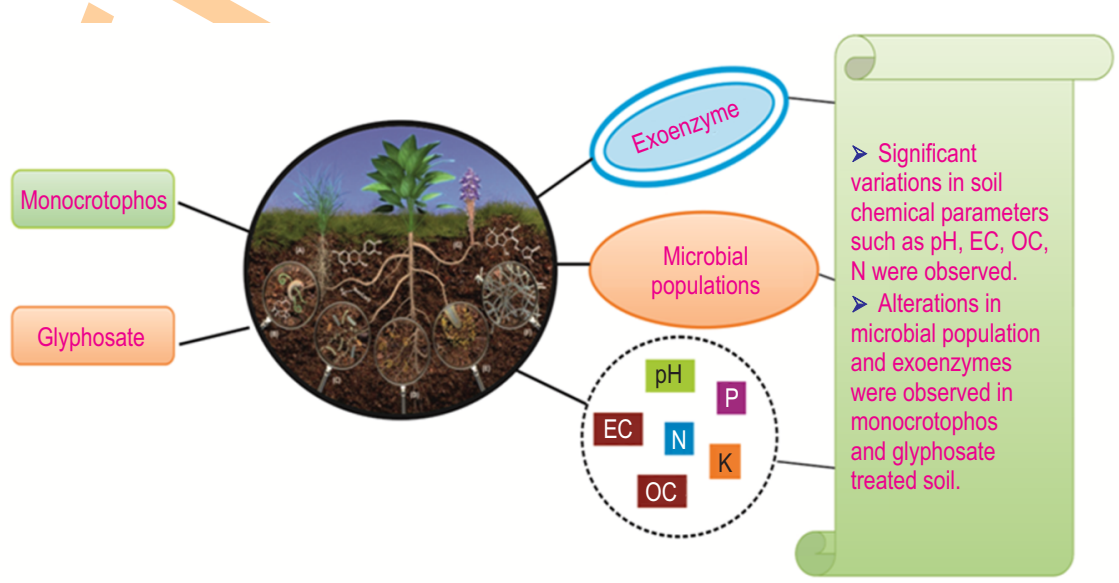

Interpretation : The study indicated that monocrotophos and glyphosate at recommended and elevated concentrations in soil could adversely impact microbial growth. Inhibited microbial population culminated in lower exoenzyme activity.

Key words: Biomarker, Exoenzymes, Glyphosate, Monocrotophos, Soil toxicity

How to cite : Samal, S., S. Sahoo and C.S.K Mishra: Evaluating the effect of monocrotophos and glyphosate on microbial population and certain important exoenzyme activities in soil. J. Environ. Biol., 40, 226-234(2019). 


\section{Introduction}

In order to protect the crops from large scale pest infestation and keep the agricultural fields free from undesirable weeds, a wide range of pesticides and herbicides are conventionally used. The amount of agrochemicals reaching the target organisms is about $0.1 \%$, while the remaining bulk contaminates the soil environment (Carriger et al., 2006; Hussain et al., 2009). With consistent rise in the use of agrochemicals in contemporary agriculture, the issue of their impact on the soil microorganisms and the processes they direct has received considerable attention (Baxter and Cummings, 2008).

Micro-organisms significantly influence decomposition and break down of organic compounds (Das and Varma, 2010). Soil health is closely integrated to the intricate interrelationship between fauna, flora and microbes. In soil, exoenzymes are mostly microbial in origin and participate actively in mineralization and decomposition of organic compounds (Sethi and Gupta, 2015). Enzymes contribute to the total biological activity of the soil-plant environment under different states (Dick, 1994, 1997). Microbial population and soil enzyme activities largely depend on optimal organic matter and other environmental conditions (Nayak et al., 2011). Agrochemicals, usually extraneous to soi component pools, are expected to affect the population of microbes and the behaviour of enzymes (Bollag and Liu, 1990; Moreno et al., 2006). Pesticides and herbicides may enter the soil by direct application (agricultural practices) or indirect applications (accidental spillage, leaks at dump sites, discharge of wastes from production facilities, urban wastes). It has been reported that both microbes and their biochemical secretions could be used to detect the level of toxicity due to xenobiotics in soil (Bollag and Liu, 1990; Filip, 2002).

In India, monocrotophos and glyphosate are commonly used organophosphate agrochemicals in crop lands for plant protection and weed management, respectively. Due to nonmechanization of application of these chemicals in the field, there is high probability of excessive application of these chemicals resulting in an elevated concentration of the residue in soil. High concentrations of these chemicals are likely to increase environmental stress on soil microbes (Sethi and Gupta, 2015) and inhibit their population and functional role. Earlier studies have shown that consistent application of insecticides can cause changes in soil properties, microbial population and their metabolic activities (Filimon et al., 2015). Growth of some microorganisms was affected by the adverse impact of herbicides (Sebiomo et al., 2011; Zain et al., 2013).

Information pertaining to the impact of monocrotophos and glyphosate on soil microbial population and their ecological functions are limited, and therefore this experimental work was undertaken to study the effects of these agrochemicals at various concentrations including the recommended agricultural dose on bacterial-fungal population, as well as the activities of certain vital soil exoenzymes.

\section{Materials and Methods}

Soil samples were collected from $0-15 \mathrm{~cm}$ depth of the organic agricultural field located in the experimental farm of Orissa University of Agriculture and Technology, Bhubaneswar, India. Samples were sieved and unwanted stones, plant and visible animal materials were removed and then transferred to rectangular earthen pots $(20 \mathrm{~cm} \times 20 \mathrm{~cm})$, each pot containing 1 $\mathrm{kg}$ of soil. Technical grades of pesticide, Monocrotophos (Monsanto) and herbicide, glyphosate (Shriram Dart Plus 71) were procured from the local market and applied to soil as per recommended agricultural doses (RAD). Recommended doses along with one low and high concentration were selected for the experiment. Monocrotophos was applied @1.0 g kg ${ }^{-1}$ soil-low (T1), $2.0 \mathrm{~g} \mathrm{~kg}^{-1}$ soil-medium (T2), $3.0 \mathrm{~g} \mathrm{~kg}^{-1}$ soil-high (T3); glyphosate at $0.1 \mathrm{~g} \mathrm{~kg}^{-1}$ soil-low (T1), $0.15 \mathrm{~g} \mathrm{~kg}^{-1}$ soil-medium (T2), $0.2 \mathrm{~g} \mathrm{~kg}^{-1}$ soilhigh (T3). Control pots were maintained with three replicates of each treated pots. Moisture was maintained at $40-50 \%$ by watering the pots every alternate day. The incubation period for the study was 84 days. Soil samples were collected at random from the experimental pots at 7 days interval for chemical and biological analysis. Soil pH and electrical conductivity (EC) were measured using digital $\mathrm{pH}$ meter and conductivity bridge (Systronics) taking soil and distilled water in 1:5 ratio (Van Reeuwijk, 1992). Soil organic carbon (OC) was measured following the method of Walkley and Black (1934). Available potassium (K) was determined using flame photometer (Jackson, 1973) and available phosphorous (P) was estimated as per Olsen et al. (1954). Acid digestion method (Hach et al., 1985) was followed to measure the available nitrogen $(\mathrm{N})$.

Microbial population (bacterial and fungal) were evaluated following serial dilution and spread plate method. Nutrient agar and potato dextrose agar plates were prepared separately for bacterial and fungal count, respectively (Parkinson et al., 1971). Soil exoenzymes (amylase, cellullase, invertase) were assayed spectrophotometrically following the method of Ross and Robert (1970) taking starch, carboxymethyl cellulose and sucrose as substrates. Soil dehydrogenase activity was observed at $485 \mathrm{~nm}$ taking $2 \%$ TTC (2, 3, 5-tri phenyl tetrazolium chloride) as per Casida et al. (1964). The method prescribed by Ladd and Butler (1972) was followed to determine soil protease activity using Tris $\mathrm{HCl}$ buffer $(0.1 \mathrm{M}, \mathrm{pH} 8.0)$. Sodium caseinate was used as substrate for this enzyme activity.

Statistical analyses : The data were analysed through two way ANOVA and DMRT with the help of SPSS-6.0 to check the level of significance between treatments at 0.05 level of significance.

\section{Results and Discussion}

In response to monocrotophos, the lowest $\mathrm{pH}$ value (6.83) was recorded at $2.0 \mathrm{~g} \mathrm{~kg}^{-1}$ soil on day 1 and the value was maximum (8.23) on day 63 at same concentration. The value was recorded to be minimum (6.8) at $0.1 \mathrm{~g} \mathrm{~kg}^{-1}$ soil glyphosate on day 7 and maximum (8.09) on day 28 at $0.15 \mathrm{~g} \mathrm{~kg}^{-1}$ soil. The maximum 
EC values were obtained $\left(0.36\right.$ and $\left.0.5 \mathrm{mS} \mathrm{cm}^{-1}\right)$ at $1.0 \mathrm{~g} \mathrm{~kg}^{-1}$ soil, $0.1 \mathrm{~g} \mathrm{~kg}^{-1}$ soil of monocrotophos and glyphosate on day 42 and day 7 , respectively. Loss in OC in soil was noticed to be maximum $\left(1.05 \mathrm{~g} \mathrm{~kg}^{-1}\right.$ soil) on day 70 with monocrotophos treatment at $2.0 \mathrm{~g}$ $\mathrm{kg}^{-1}$ soil. Nitrogen values were minimum $\left(1.1,0.8 \mathrm{~g} \mathrm{~kg}^{-1}\right.$ soil) on day 77 in soils with $3.0 \mathrm{~g} \mathrm{~kg}^{-1}$ soil, $0.2 \mathrm{~g} \mathrm{~kg}^{-1}$ soil of monocrotophos and glyphosate, respectively. Phosphorus was found to be lowest (0.01, $0.02 \mathrm{~g} \mathrm{~kg}^{-1}$ soil) at $3.0 \mathrm{~g} \mathrm{~kg}^{-1}$ soil, $0.2 \mathrm{~g} \mathrm{~kg}^{-1}$ soil of monocrotophos and glyphosate on days 21 and 77 . Potassium values were found to be very low at different concentrations and treatments and varied in the range between $0.01-0.03 \mathrm{~g} \mathrm{~kg}^{-1}$ soil. The mean along with standard error of all the soil chemical parameters are presented in Table 1. All the parameters, except available $P$ and $K$, indicated significant variations $(p<0.05)$ from each other and with respect to control.
Earlier reports (Yargholi and Azarneshan, 2014) indicated that soil $\mathrm{pH}$ and $\mathrm{EC}$ differed significantly due to pesticide and fertilizer use. Tariq et al. (2016) reported elevated conductivity in soil due to high amount of metal ions in fertilizers. Tahar et al. (2017) reported increase in EC and variation in other physico-chemical parameters of pesticide treated soil which depended on the nature of the pesticide and the doses used. The results of the present study are consistent with these earlier findings. Nayak et al. (2011) observed an enhanced reduction in percent OC after treatment with various concentrations of phosphogypsum in soil, and proposed that $\mathrm{OC}$ reduction could be correlated to microbial respiration and enzyme activity. Baboo et al. (2003) had earlier observed significant variation in soil organic carbon in different herbicide treated soils and suggested that at high concentration, there was noticeable reduction in carbon loss

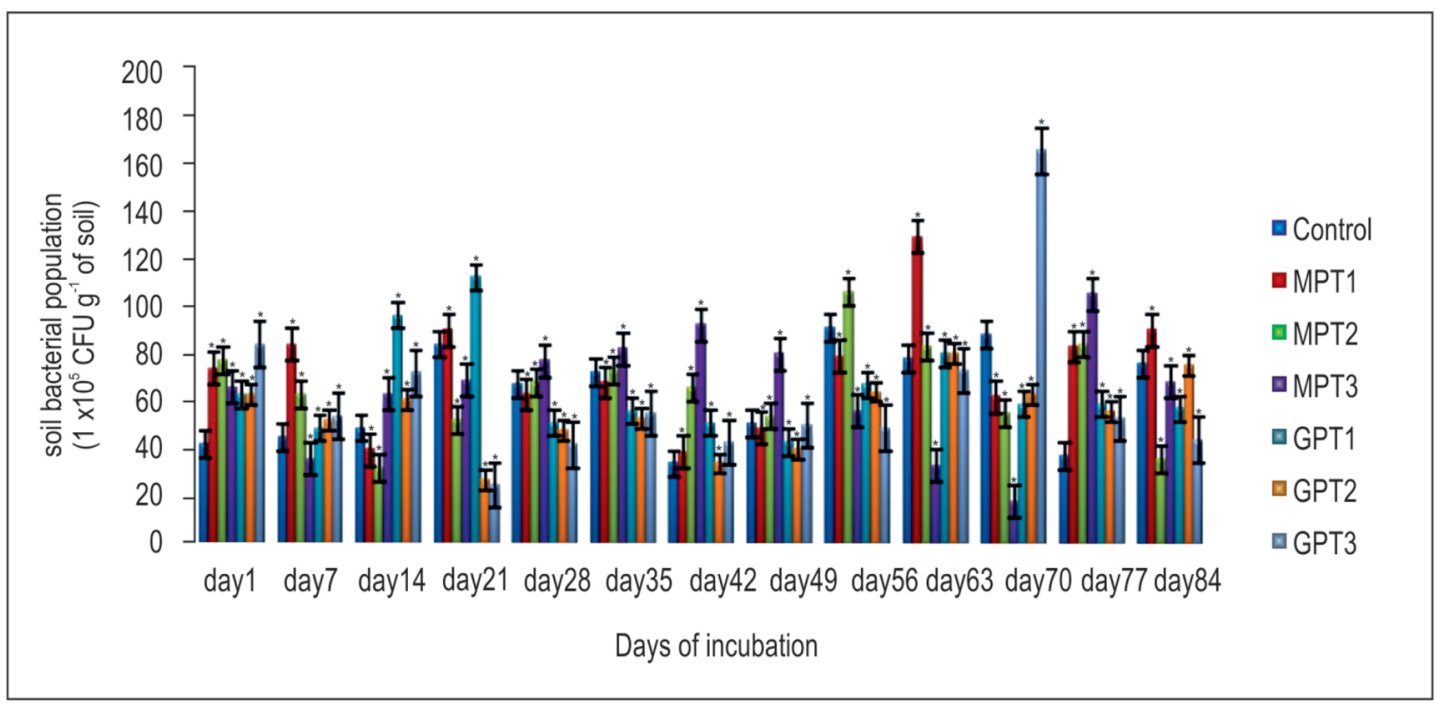

Fig. 1a: Change in the soil bacterial population treated with monocrotophos (MP) and glyphosate (GP); ${ }^{*}$ indicates significance at $p<0.05$.

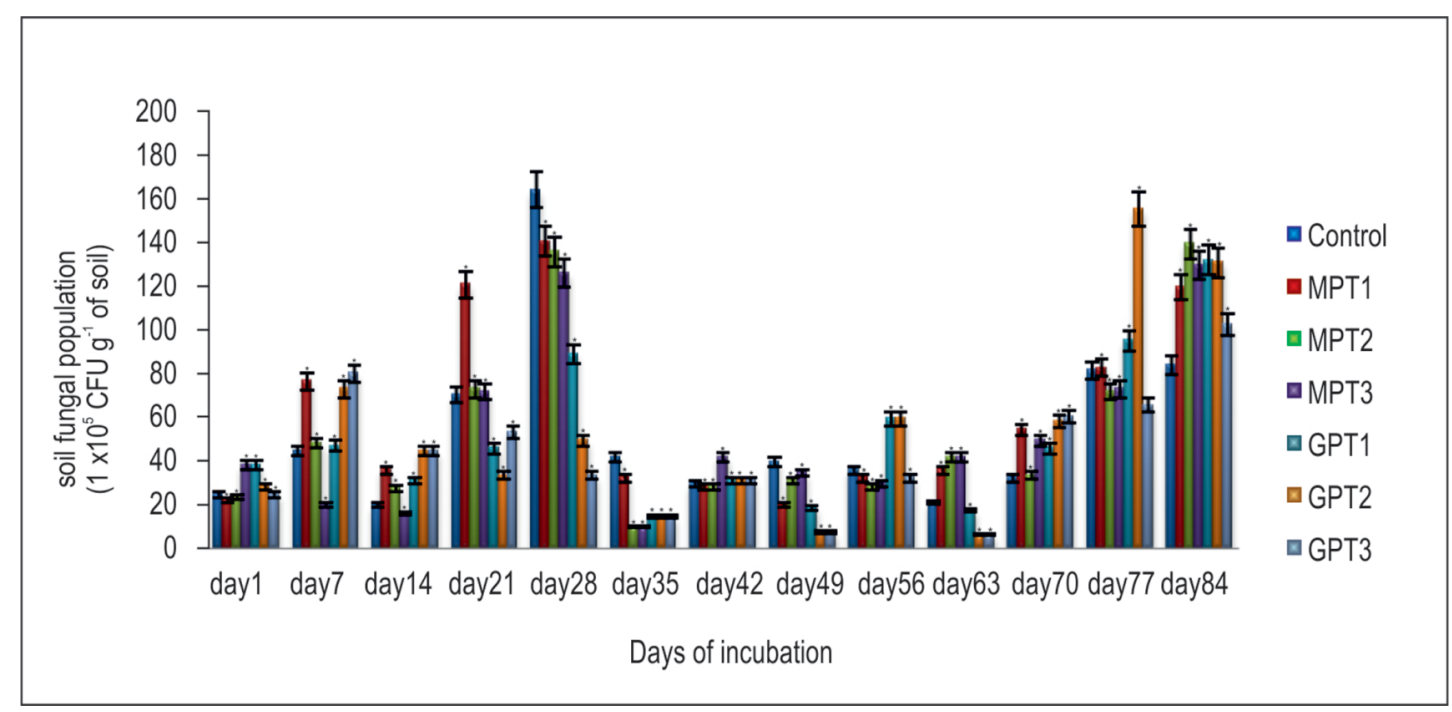

Fig. 1b: Change in the soil fungal population treated with monocrotophos (MP) and glyphosate (GP); * indicates significance at $p<0.05$. 

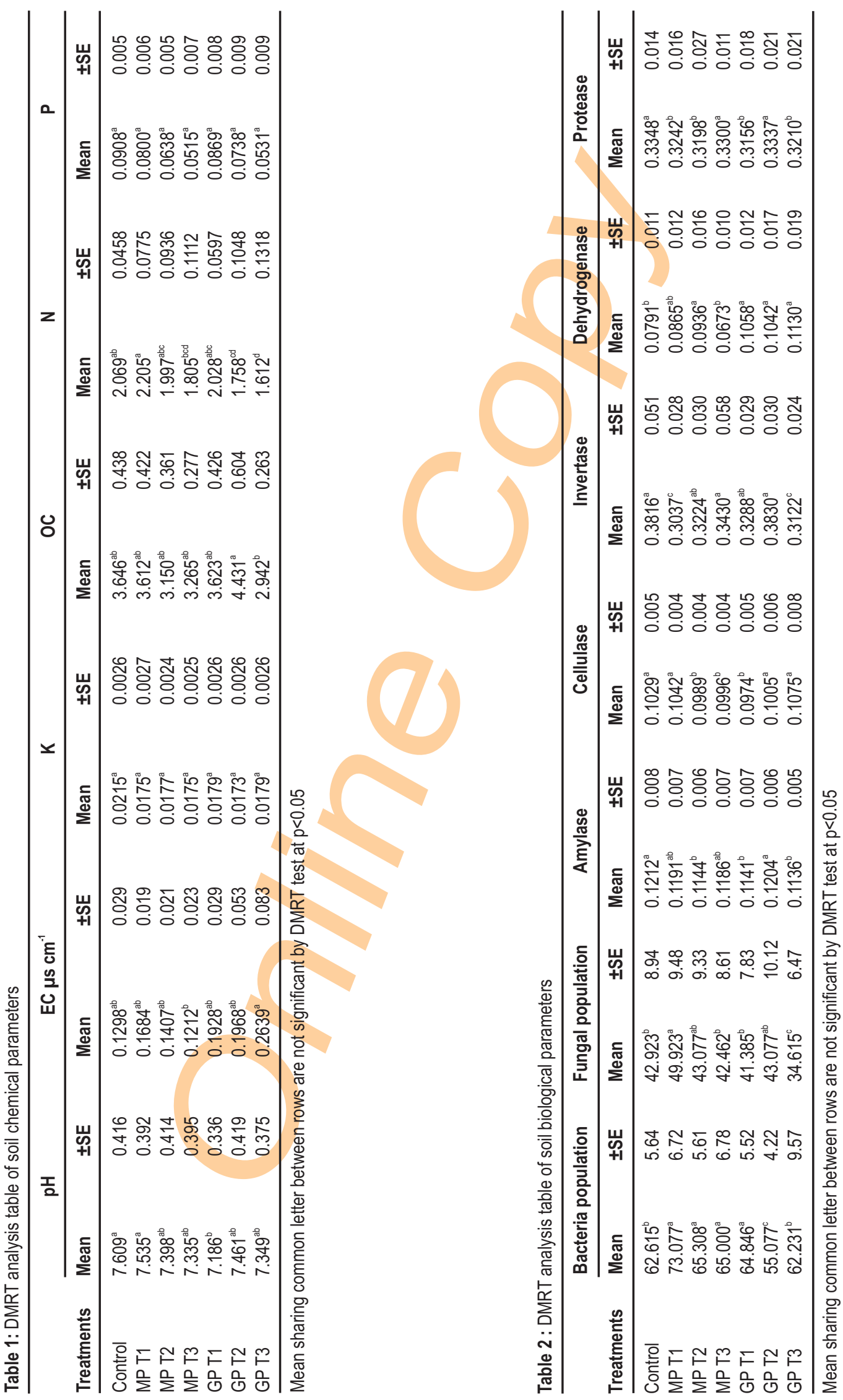


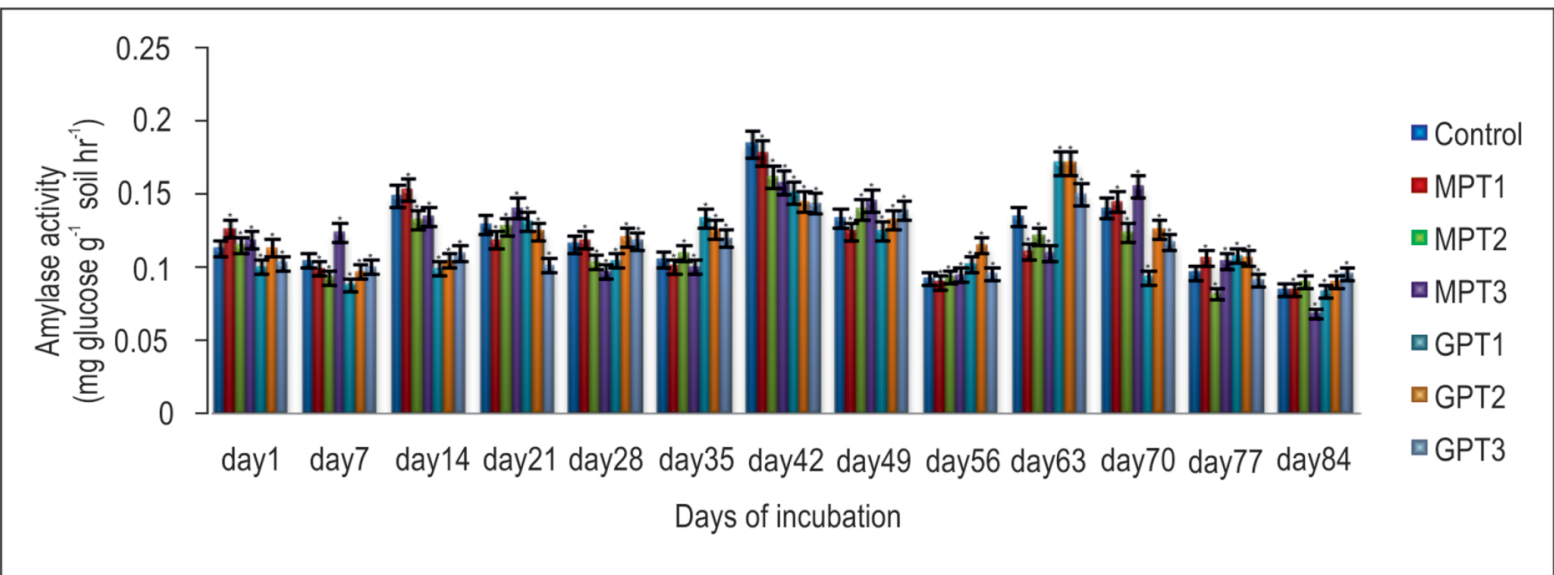

Fig. 2a : Change in soil amylase activity treated with monocrotophos (MP) and glyphosate (GP); * indicates significance at $p<0.05$.

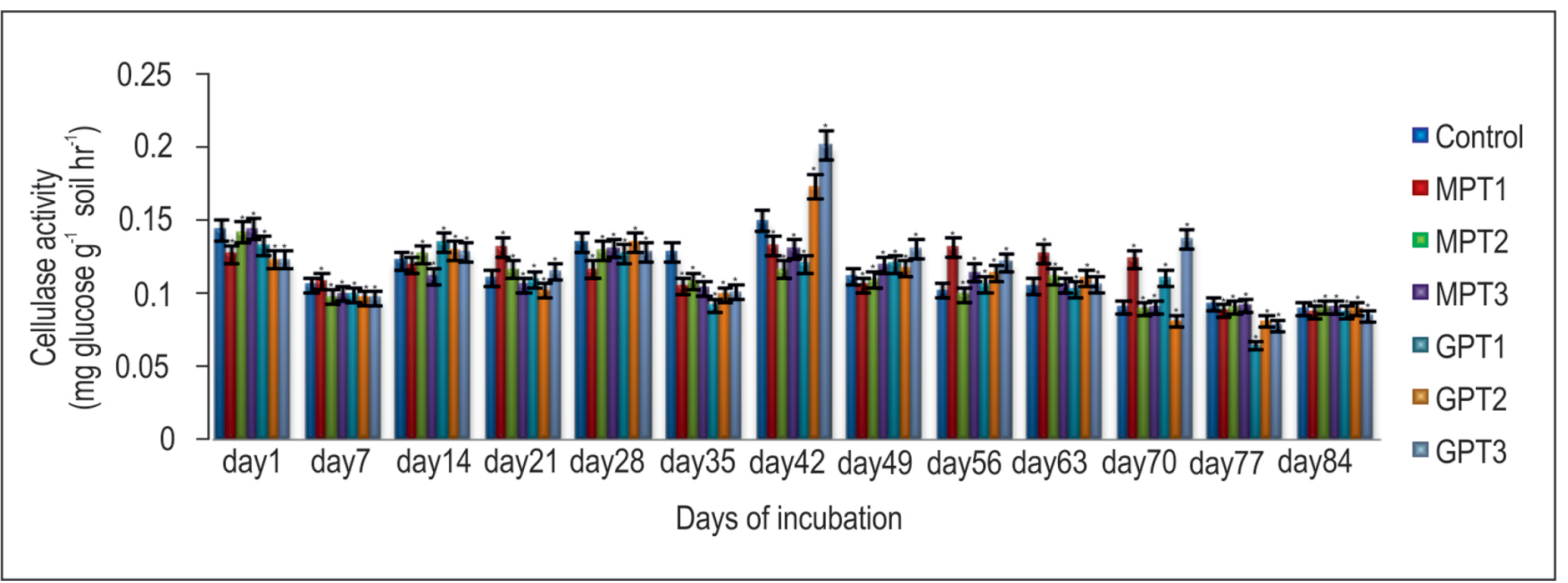

Fig. 2b: Change in soil cellulase activity treated with monocrotophos (MP) and glyphosate (GP); * indicates significance at p<0.05.

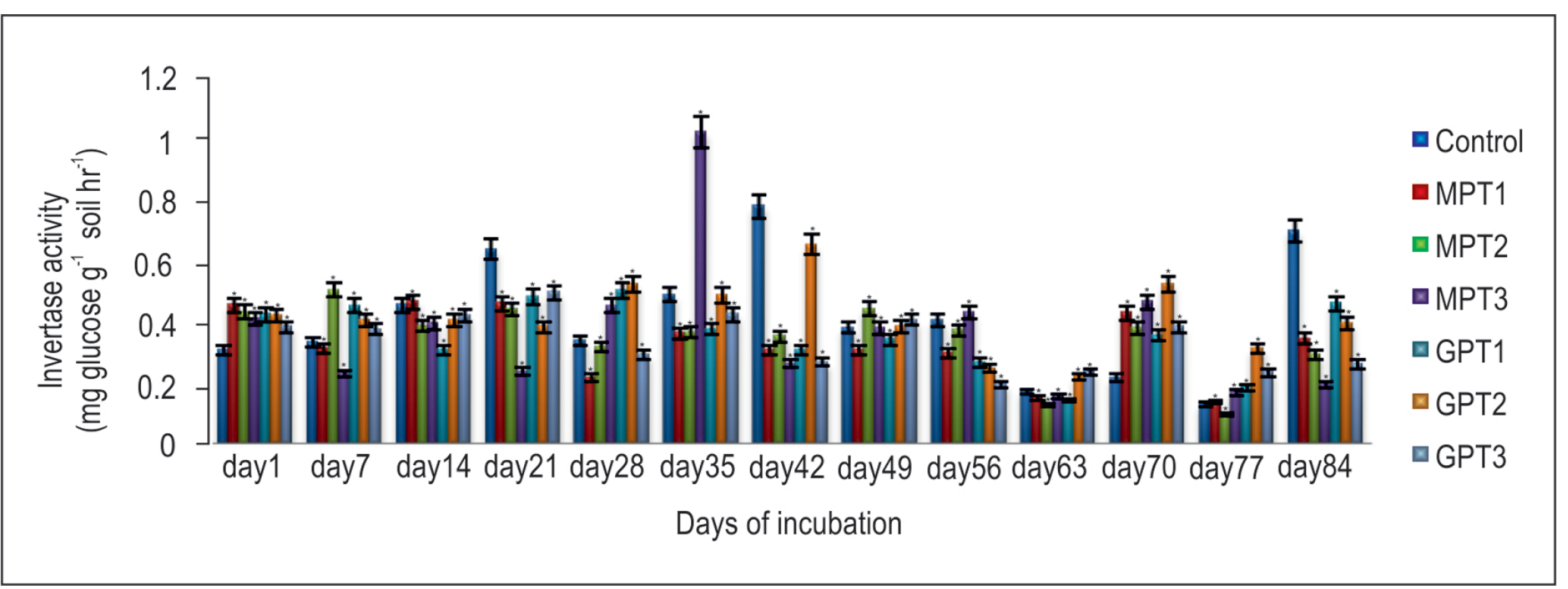

Fig. 2c: Change in soil invertase activity treated with monocrotophos (MP) and glyphosate (GP); * indicates significance at $p<0.05$. 


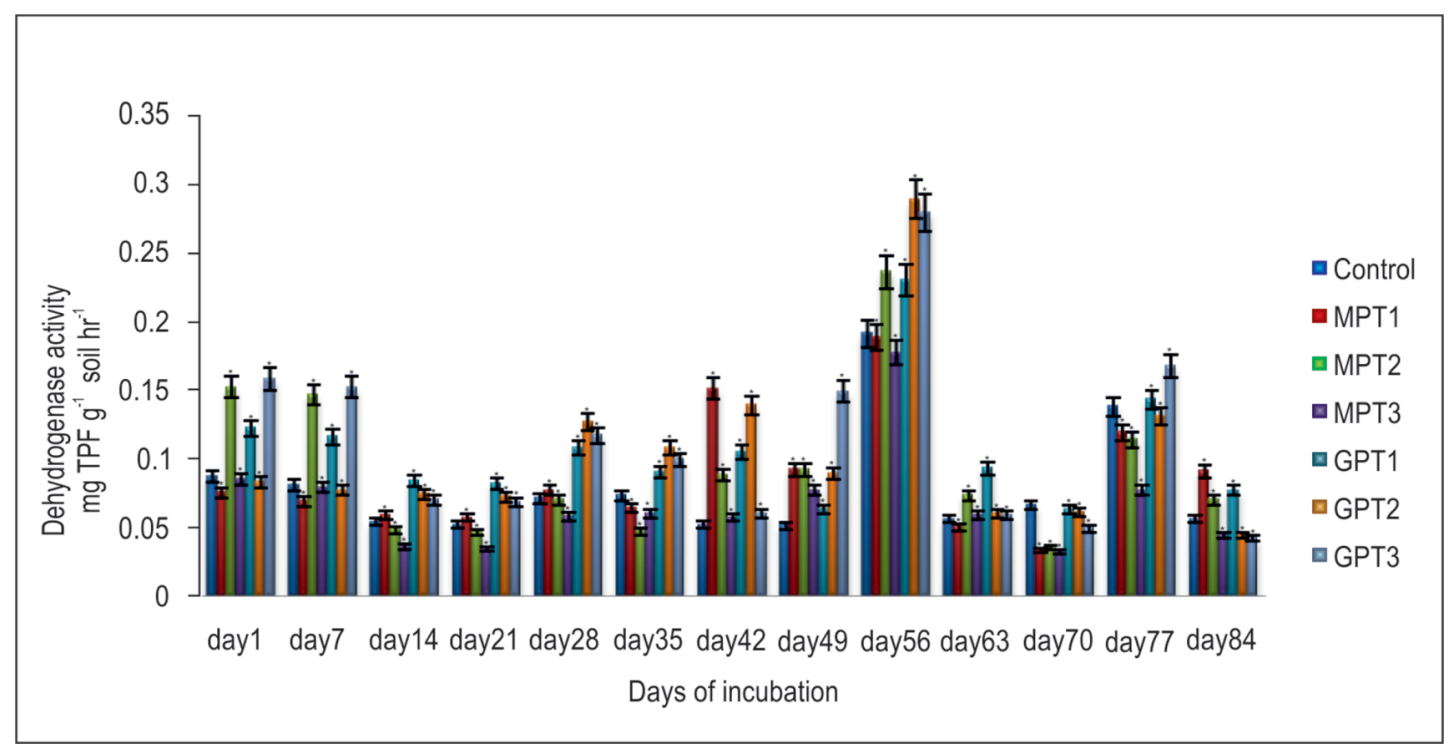

Fig. $2 \mathrm{~d}$ : Change in soil dehydrogenase activity $\left(\mathrm{mg} \mathrm{TPF} \mathrm{g}^{-1}\right.$ soil $\left.\mathrm{hr}^{-1}\right)$ treated with monocrotophos (MP) and glyphosate (GP); ${ }^{*}$ indicates significance at $p<0.05$.

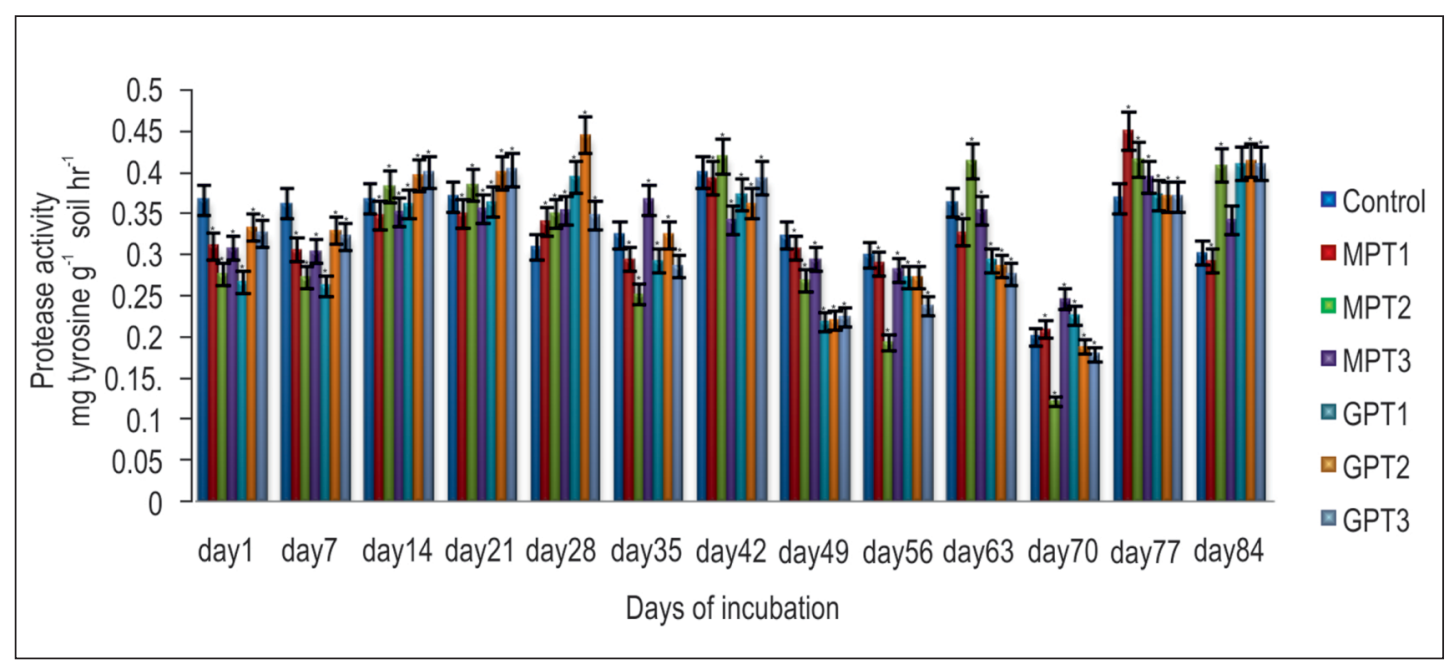

Fig. $2 \mathrm{e}$ : Change in soil protease activity (mg tyrosine $\mathrm{g}^{-1}$ soil $\left.\mathrm{hr}^{-1}\right)$ treated with monocrotophos (MP) and glyphosate (GP); * indicates significance at $p<$ 0.05 .

relative to control soil. In this study, it was observed that soil treated with monocrotophos and glyphosate negatively impacted loss of OC which is likely due to lower microbial activity in agrochemical treated soils relative to control.

The mean along with standard error of all the soil biological parameters are presented in Table 2 . It is evident that the mean values of all the biological parameters (microbial population and exoenzymes) at all treatments were found to be significantly different from the control $(p<0.05)$. On day 70 , the soil bacterial population declined by $79.7 \%$ in response to $3.0 \mathrm{~g} \mathrm{~kg}^{-1}$ soil of monocrotophos. However on day 77 , the population increased by $183.7 \%$ at $3.0 \mathrm{~g} \mathrm{~kg}^{-1}$ soil of monocrotophos. Glyphosate treated soil showed an increase in bacterial population by $100 \%$ on day 1 , but subsequently the population decreased by $70 \%$ on day 21 . On day 84 , the maximum reduction in bacterial population up to $135.9 \%$ and $142.1 \%$ were noted at $2.0 \mathrm{~g} \mathrm{~kg}^{-1}$ soil of monocrotophos and $0.2 \mathrm{~g} \mathrm{~kg}^{-1}$ soil of glyphosate, respectively. The bacterial population increased by $40.8 \%$ at 0.15 $\mathrm{g} \mathrm{kg}^{-1}$ soil of glyphosate (Fig. 1a). Monocrotophos @ $3.0 \mathrm{~g} \mathrm{~kg}^{-1}$ soil decreased the fungal population by $64.8 \%$ on day 35 , which subsequently increased by $104 \%$ on day 63 . Glyphosate induced maximum fungal growth by $130.25 \%$ on day 14 at $0.2 \mathrm{~g} \mathrm{~kg}^{-1}$ soil. On day 84 , fungal population indicated a reduction by $0.58 \%$ at 
$3.0 \mathrm{~g} \mathrm{~kg}^{-1}$ soil of monocrotophos. The percent fungal population declined by $81.25 \%$ on day 49 of glyphosate treatment (Fig. 1 b). Lo (2010) reported that the organophosphate insecticide fenamiphos at elevated concentration was detrimental to nitrification bacteria in soil. Microbial populations and their functional attributes influenced by pesticides have been used as guidelines to evaluate the ecological safety of soil. Zhou et al. (2012) studied the effects of two agrochemicals carbofuran and butachlor at $10 \mathrm{mg} \mathrm{kg}^{-1}$ and carbofuran at $0.5 \mathrm{mg} \mathrm{kg}^{-1}$ significantly inhibited the population of methane producing and nitrogen fixing bacteria. It has been observed that the herbicides glyphosate, atrazine, paraquat reduced the soil microbial population (Sebiomo et al., 2011; Adomako and Akyeampong, 2016).

The present study indicated a temporary increase in microbial population which subsequently declined. Bera and Ghosh (2013) have highlighted the herbicide degradation property of microorganisms and also observed the toxic impact of herbicide treatment on soil micro-organisms. The results of the present study corroborate the findings of the above studies and reaffirm the fact that herbicides and pesticides prove detrimental to microbial growth in soil.

Soil amylase activity increased by $18.4 \%$ on day 7 , and subsequently declined by $21 \%$ on day 84 with $3.0 \mathrm{~g} \mathrm{~kg}^{-1}$ soil of monocrotophos. Glyphosate treatment @ $0.1 \mathrm{~g} \mathrm{~kg}^{-1}$ soil decreased the activity by $37.8 \%$ on day 70 whereas the activity showed a significant increase of $28 \%$ on day 63 with $0.15 \mathrm{~g} \mathrm{~kg}^{-1}$ soil of glyphosate. On day 84 , the percent reduction in amylase activity was $25.4 \%$ at $3.0 \mathrm{~g} \mathrm{~kg}^{-1}$ soil of monocrotophos. There was maximum increment in amylase activity (21.1\%) at $0.2 \mathrm{~g} \mathrm{~kg}^{-1}$ soil of glyphosate (Fig. 2a). Cellulase activity reduced by $22.4 \%$ on day $42 \mathrm{at}^{2.0 \mathrm{~g} \mathrm{~kg}^{-1}}$ soil of monocrotophos. A maximum reduction of $30.5 \%$ in this enzyme activity was observed on day 77 in response to glyphosate treatment. On day 84 , cellulase activity increased by $10 \%$ and $15 \%$ at $1.0 \mathrm{~g} \mathrm{~kg}^{-1}$ soil of monocrotophos, $0.15 \mathrm{~g} \mathrm{~kg}^{-1}$ soil glyphosate, respectively (Fig. 2b). Monocrotophos @ $3.0 \mathrm{~g} \mathrm{~kg}^{-1}$ soil and glyphosate @ $0.2 \mathrm{~g} \mathrm{~kg}^{-1}$ soil inhibited invertase activity by $72 \%$ and $65 \%$, respectively, on day 84 (Fig. 2C). On day 70 , the dehydrogenase activity declined by $51.6 \%$ and $25.8 \%$ with $3.0 \mathrm{~g} \mathrm{~kg}^{-1}$ soil of monocrotophos and $0.2 \mathrm{~g} \mathrm{~kg}^{-1}$ soil of glyphosate, respectively. On day 84 , dehydrogenase activity decreased by $19.2 \%$ and $106.6 \%$ at $2.0 \mathrm{~g}$ $\mathrm{kg}^{-1}$ soil of monocrotophos and $0.2 \mathrm{~g} \mathrm{~kg}^{-1}$ soil of glyphosate, (Fig. $2 \mathrm{~d}$ ). Monocrotophos @ $2.0 \mathrm{~g} \mathrm{~kg}^{-1}$ soil showed maximum inhibitory effect of $39 \%$ on soil protease activity on day 70 . However, this enzyme activity decreased by $32.6 \%$ in response to low $0.1 \mathrm{~g} \mathrm{~kg}^{-1}$ soil of glyphosate on day 49 . On day 84 , the enzyme activity was stimulated by $59.6 \%$ and $46.6 \%$ in response to $2.0 \mathrm{~g} \mathrm{~kg}^{-1}$ soil of monocrotophos and $0.2 \mathrm{~g}$ $\mathrm{kg}^{-1}$ soil of glyphosate, respectively (Fig. 2e).

Amylases are synthesized by plants, animals and microorganisms. They play a significant role in the breakdown of starch into glucose or maltose (Thoma et al., 1971). This enzyme is influenced by agricultural practices (Das and Varma, 2010). Deborah et al. (2013) observed the inhibitory effects of pesticides at higher concentration on soil enzymes and microbes. Mohiddin et al. (2010, 2013) observed that the organophosphorus insecticides monocrotophos and quinalphos along with two pyrethroid, cypermethrin and fenvalerate with concentration ranging from $1.0-2.5 \mathrm{~kg} \mathrm{ha}^{-1}$ enhanced amylase activity in groundnut soil. However, at high concentration of 5 and $10 \mathrm{~kg} \mathrm{ha}^{-1}$, the insecticides were toxic to this enzyme activity.

The inhibitory effects of monocrotophos and glyphosate on amylase activity in the present study support these findings and indicate that organophosphates at elevated concentrations could suppress soil amylase activity. Cellulase acts as catalyst on cellulose degradation and is mostly produced by bacteria and fungi. Soil treated with some fungicides and pesticides at recommended doses had deleterious effects on cellulase activity in laboratory condition (Das and Varma, 2010). Sethi and Gupta (2015) have determined the notable inhibitory effects of cellulase activity in response to heavy metals. Riah et al. (2014) proposed that insecticides which belong to organophosphate family have stimulating effects on cellulase activity. These insecticides destroy soil insects and make substrate available to stimulate cellulase activity (Niemi et al., 2009). In the present study, 10\% and $15 \%$ increase in cellulase activity at low and medium concentration of monocrotophos and glyphosate are in agreement with these earlier observations. Invertase synthesized by microorganisms, animals and plants catalyse the hydrolysis of sucrose to D-glucose and D-fructose. Singh et al. (2002) reported that the insecticides such as chloropyriphos, fenamiphos and chlorothalonil alone and in combination suppress invertase activity through their inhibitory influence on microbes. In the present study a significant reduction in the activity of invertase due to both the test chemicals agree to the proposal that organophosphates exert inhibitory effects on soil invertase activity.

Dehydrogenase enzyme is involved in respiration and energy production of micro-organisms. Reports are available on toxic effects of insecticides at higher concentration (Mayanglambam et al., 2005; Cycoń et al., 2010). Organophosphates pesticides (Kalam et al., 2004) and herbicides (Xia et al., 2011) have repressive effects on dehydrogenase activity because of their inhibitory influence on soil micro-organisms. The reduction in the dehydrogenase activity in soil in the present study is in agreement with these earlier reports.

Protease contributes significantly in plant growth by involving in nitrogen mineralization. This enzyme acts as catalyst in breakdown of proteinaceous substances in soil. The protease activity increased in soil treated with both monocrotophos and glyphosate relative to the control after an initial decline. Ramudu et al. (2012) observed the inhibitory effects of protease due to toxicity of insecticides. They reported that enzyme is sensitive to endosulfan and profenophos. Effron et al. (2004) found that heavy metals reduced the soil protease activities. The results of the present study are similar to these previous reports. The results of the present study indicated a wide variation in microbial population and activities of all the exoenzymes in soil treated with monocrotophos and glyphosate. Although different enzymes responded differently to the test agrochemical concentrations, in 
general inhibitory effects of these chemicals on the microbes and enzymes was observed.

The interpretation of enzymatic responses to the treatment of agrochemicals in soil are difficult, since the observed responses might be the result of diverse factors. For example, the agrochemicals could bind to the active site of the enzyme which affects their catalytic activities or sometimes the micro-organisms use the chemicals as source of nutrient which affect the biosynthesis and activity of the enzymes (Cycon et al., 2006; Tejada, 2009; Zabaloy et al., 2012; Chishti et al., 2013). This stimulation or suppression of soil microbial community which is likely due to the impact of these chemicals lead to their functional redundancy (Puglisi et al., 2012; Griffiths and Philippot, 2013).

It is, therefore, concluded that the micro-organisms and exoenzymes in soil are highly sensitive to soil contamination and could be used as ideal indicators to detect toxicity caused by agrochemicals so that remedial measures can be adopted for reduction in contamination and ensure minimal impact on beneficial soil biota.

\section{Acknowledgment}

The authors are thankful to the Science and Technology Department, Government of Odisha, India for financial support.

\section{References}

Adomako, M. O. and S. Akyeampong: Effect of some commonly used herbicides on soil microbial population. J. Environ. Earth Sci., 6 30-38 (2016).

Baboo, M., M. Pasayat, A. Samal, M. Kujur, J. K. Maharana and A. K. Patel: Effect of four herbicides on soil organic carbon, microbial biomass-C, enzyme activity and microbial populations in agricultural soil. Int. J. Res. Environ. Sci. Technol., 3, 100-112 (2013).

Baxter, J. and S. P. Cummings: The degradation of the herbicide bromoxynil and its impact on bacterial diversity in a top soil. J. Appl. Microbio., 104,1605-1616 (2008).

Bera, S. and R.K. Ghosh: Soil microflora and weed management as influenced by atrazine 50\% WP in sugarcane. Universal J. Agricult. Res., 1, 41-47 (2013).

Bollag, J.M. and S.Y. Liu: Biological transformation processes of pesticides. In: Pesticides in the Soil Environment: Processes, Impact and Modelling (Ed.: H.H Cheng). Soil Science Society of America, Madison, WI, USA, pp. 169-211(1990).

Carriger, J. F., G. M. Rand, P. R. Gardinali, W. B. Perry, M. S. Tompkins and A. M. Fernandez: Pesticides of potential ecological concern in sediment from South Florida canals: An ecological risk prioritization for aquatic arthropods. Soil Sedi. Contamin., 15, 2145 (2006).

Casida, L., D. Klein and T. Santoro: Soil dehydrogenase activity. Soil Sci., 98, 371-376 (1964)

Chishti, Z., S. Hussain, K. R. Arshad, A. Khalid and M. Arshad: Microbial degradation of chlorpyrifos in liquid media and soil. J. Environ. Manage., 114, 372-380 (2013).

Cycoń, M., Z. Piotrowska-Seget and J. Kozdrój: Microbial characteristics of sandy soils exposed to diazinon under laboratory conditions. World J. Microbiol. Biotechnol., 26, 409-418 (2010).
Cycoń, M., Z. Piotrowska-Seget, A. Kaczyńska and J. Kozdrój: Microbiological characteristics of a sandy loam soil exposed to tebuconazole and $\lambda$-cyhalothrin under laboratory conditions. Ecotoxicology, 15, 639-646 (2006).

Das, S. K. and A. Varma: Role of enzymes in maintaining soil health In: Soil Enzymology. Springer Berlin Heidelberg, pp. 25-42 (2010).

Deborah, B. V., M. J. Mohiddin and R. J. Madhuri: Interaction effects of selected pesticides on soil enzymes. Toxicology Inter., 20, 195 (2013)

Dick, R. P.: Soil enzyme activities as indicators of soil quality. In: Defining Soil Quality for a Sustainable Environment. Madison, Wisconsin, USA: SSSA, pp. 107-124 (1994).

Dick, R.: Soil enzyme activities as integrative indicators of soil health. In: Biological Indicators of Soil Health. CAB International, New York, USA, pp. 121-156 (1997)

Effron, D., A.M. de la Horra, R.L. Defrieri, V. Fontanive and P.M. Palma: Effect of cadmium, copper and lead on different soil enzymatic activities in a native forest soil. Comm. Soi. Sci. Plant Anal., 35 1309-1321 (2004)

Filimon, M. N., S.O. Voia and R. Popescu, G.A.B.I. Dumitrescu, L. P. Ciochina, M. Mituletu and D.C. Vlad: The effect of some insecticides on soil microorganisms based on enzymatic and bacteriological analyses. Rom. Biotechnol. Lett., 20, 10439-10447 (2015).

Filip, Z.: International approach to assessing soil quality by ecologicallyrelated biological parameters. Agric. Ecosyst. Environ., 88, 169174 (2002).

Griffiths, B. S. and L. Philippot: Insights into the resistance and resilience of the soil microbial community. FEMS Microbiol. Rev., 37, 112-129 (2013).

Hach, C.C., B.K. Bowden, A.B. Kopelove and S.V. Brayton: More powerful peroxide kjeldahl digestion method. J. Assoc. Off. Anal. Chem., 70, 783-787 (1985).

Hussain, S., T. Siddique, M. Saleem, M. Arshad and A. Khalid: Impact of pesticides on soil microbial diversity, enzymes, and biochemical reactions. Advances in Agronomy, 102, 159-200 (2009).

Jackson, M.L.: Soil Chemical Analysis. Prentice Hall of India, 1qq NewDelhi, p. 365(1973).

Kalam, A., J. Tah and A. K. Mukherjee : Pesticide effects on microbial population and soil enzyme activities during vermicomposting of agricultural waste. J. Environ. Biol., 25, 201-208 (2004).

Ladd, J.N. and J.H.A. Butler: Short-term assays of soil proteolytic enzyme activities using proteins and dipeptide derivatives as substrates. Soil Biol. Biochem., 4, 19-30 (1972).

Lo, C. C.: Effect of pesticides on soil microbial community. J. Environ. Sci. HIth. B., 45, 348-359 (2010)

Mayanglambam, T., K. Vig and D.K. Singh: Quinalphos persistence and leaching under field conditions and effects of residues on dehydrogenase and alkaline phospho monoesterases activities in soil. Bull. Environ. Contam. Toxicol., 75, 1067-1076 (2005).

Mohiddin, G. J., K. Subramanyam, V. Rangaswamy, M. Srinivasulu and M. Madakka: Influence of insecticides flubendiamide and spinosad on biological activities in tropical black and red clay soils. 3 Biotech., 5, 13-21 (2013).

Mohiddin, G. J., M. Srinivasulu, M. Madakka and V. Rangaswamy: Influence of insecticides on the activity of amylase and cellulase in groundnut (Arachis hypogaea L.) soil. Ecol. Environ. Conserv., 3, 383-388 (2010).

Moreno, J.L., A. Sanchez-Marín, T. Hernández and C. Garía: Effect of cadmium on microbial activity and a ryegrass crop in two semiarid soils. Environ. Manag., 37, 626-633 (2006).

Nayak, S., C.S.K. Mishra, B.C. Guru and M. Rath: Effect of phosphogypsum amendment on soil physico-chemical properties, microbial load and enzyme activities. J. Environ. Biol., 32, 613-617 (2011). 
Niemi, R. M., I. Heiskanen, J. H. Ahtiainen, A. Rahkonen, K. Mäntykoski, L. Welling, P. Laitinen and P. Ruuttunen: Microbial toxicity and impacts on soil enzyme activities of pesticides used in potato cultivation. Appl. Soil. Ecol., 41, 293-304 (2009).

Olsen, S.R., C.V. Cole, F.S. Watanabe and L.A. Dean: Estimation of phosphorous in soil by extracting with sodium bicarbonate. USDA Circular, 939, 19 (1954).

Parkinson, D., T.R.G. Gray and S.T. William: Methods to study ecology of soil microorganisms. IBP Handbook No. 19, Blackwell Scientific Publ. Oxford, p. 116 (1971).

Puglisi, E., S. Vasileiadis, K. Demiris, D. Bassi, D.G. Karpouzas, E. Capri, P.S. Cocconcelli and M. Trevisan: Impact of fungicides on the diversity and function of non-target ammonia-oxidizing microorganisms residing in a litter soil cover. Microb. Ecol., 64 692-70 (2012).

Ramudu, A.C., M. Srinivasulu, G.J. Mohiddin and V. Rangaswamy: Effect of fungicides on urease and protease activities in two groundnut (Arachis hypogaea L.) soils. Int. J. Environ. Protec., 2, 23-28 (2012).

Riah, W., K. Laval, C. Mougin, E. Laroche-Ajzenberg, X. Latour and I Trinsoutrot-Gattin: Effects of pesticides on soil enzyme: A review. Environ. Chem. Lett., 12, 257-273 (2014).

Ross, D.J. and H.S. Roberts: Enzyme activities and oxygen uptake of soi under pasture in temperature and rainfall sequence. J. Soil Sci., 21,368-381(1970)

Sebiomo, A., V. W. Ogundero and S. A. Bankole: Effect of four herbicides on microbial population, soil organic matter and dehydrogenase activity. African J. Biotechnol., 10, 770-778 (2011).

Sethi, S. And S. Gupta: Responses of soil enzymes to different heavy metals. Biolife, 3, 147-153 (2015).

Singh, B.K., W. Allan and J.W. Denis: Degradation of chlorpyrifos, fenamiphos, and chlorothalonil alone and in combination and their effects on soil microbial activity. Enviro. Toxicol. Chem., 21, 26002605 (2002).

Tahar, W., O. Bordjiba and L. Mezedjir.: Impact of two pesticides on soil physicochemical characteristics and the biological activity. J.
Chemi. Pharmace. Sci. 10, 803-808 (2017).

Tariq, S. R., M. Shafiq and G. A. Chotana: Distribution of heavy metals in the soils associated with the commonly used pesticides in cotton fields. Scientifica, 2016, 1-11(2016).

Tejada, M.: Evolution of soil biological properties after addition of glyphosate, diflufenican and glyphosate+ diflufenican herbicides. Chemosphere, 76, 365-373 (2009).

Thoma, J.A, J.E. Spradlin and S. Dygert: Plant and animal amylases. In: The Enzymes (Ed.: P.D. Boyer). $5^{\text {th }}$ Edn., Academic, New York, pp.115-189(1971).

Van Reeuwijk, L. P.: Proceedings for Soil Analysis. $3^{\text {rd }}$ Edn., International soil Reference and Information Center (ISRIC), Wangeningen, The Netherlands (1992).

Walkley, A. and I.A. Black: An examination of the Degtjareff method for determining organic carbon in soils. Effect of variations in digestion conditions and of inorganic soil constituents. Soil Sci., 63, 251-263 (1934).

Xia, X., M. Zhao, H. Wang and H. Ma:Influence of butachlor on soil enzymes and microbial growth. J. Food Agric. Environ., 9, 753-756 (2011).

Yargholi, B. And S. Azarneshan: Long-term effects of pesticides and chemical fertilizers usage on some soil properties and accumulation of heavy metals in the soil (case study of Moghan plain's (Iran) irrigation and drainage network). Int. J. Agricult. Crop Sci., 7, $518(2014)$.

Zabaloy, M. C., E. Gómez, J. L. Garland and M. A. Gómez: Assessment of microbial community function and structure in soil microcosms exposed to glyphosate. Appl. Soil Ecol., 61, 333-339 (2012).

Zain, N.M.M., R.B. Mohamad, K. Sijam, M.M. Morshed and Y. Awang: Effects of selected herbicides on soil microbial populations in oil palm plantation of Malaysia: A microcosm experiment. African J. Microbiol. Res., 7, 367-374 (2013).

Zhou, X., X. Shi, L. Zhang and Y. Zhou: Effects of pesticidecontamination on population and activity of bacteria in purple paddy soil. Energy Procedia, 16, 284-289 (2012). 